\title{
Vitamin D Deficiency Among Patients with COVID-19 : Case Series and Recent Literature Review
}

\author{
Rizaldy Taslim Pinzon \\ Duta Wacana Christian University Medical of School https://orcid.org/0000-0002-3357-9907 \\ Angela Angela ( $\sim$ saint.angel46@gmail.com) \\ Duta Wacana Christian University Medical of School https://orcid.org/0000-0002-8891-8953 \\ Andryawan Wahyu Pradana \\ Duta Wacana Christian University Medical of School https://orcid.org/0000-0003-1363-999X
}

\section{Research Article}

Keywords: Coronavirus, COVID-19, Vitamin D, Vitamin D Deficiency, Low Vitamin D

Posted Date: May 21st, 2020

DOI: https://doi.org/10.21203/rs.3.rs-29473/v1

License: (c) (1) This work is licensed under a Creative Commons Attribution 4.0 International License. Read Full License 


\section{Abstract}

Background The world is now challenging the pandemic of COVID-19 infection. Previous studies showed the plausibility of Vitamin D prophylaxis and therapy for COVID-19, particularly in settings where hypovitaminosis D is frequent. Recent study from Indonesian showed that prevalence of vitamin D deficiency were $23.0 \%$. The examination of Vitamin $D$ status is not a routine in Indonesian clinical setting.

Methods This study is a Case Series from confirmed cases of COVID-19 in Bethesda hospital Yogyakarta Indonesia. The data of clinical symptoms, clinical signs, and laboratory examination were obtained from electronic medical record. The vitamin $D$ status was measured by standardized laboratory method. We searched PubMed and Google Scholar for studies that included terms for Vitamin D and COVID-19.

Results The data was obtained from 10 participants consist of $50 \%$ male and $50 \%$ female. The mean of age was 49.6 years. The prevalence of vitamin D deficiency in this case was $90 \%$ and $10 \%$ of insufficiency. Patients in this case had various symptom and also had various chronic disease as comorbidity.

Conclusions The prevalence of vitamin D deficiency in this case series in Bethesda hospital Yogyakarta, Indonesia is $90 \%$ and $10 \%$ vitamin D insufficiency. We found no clinical evidence that vitamin D supplements are beneficial in preventing or treating COVID-19. Randomized controlled trials need to determine and evaluated this recommendation.

\section{Background}

The world is now challenging the pandemic of coronavirus (CoV) infections, the disease that called COVID-19. A new CoV infection epidemic began in Wuhan, China, in late 2019 [1]. This is the third and most extensive pandemic after the first severe acute respiratory syndrome (SARS)-CoV, which started in China in 2002 [2].

Indonesia is a tropical country with abundant sun exposure, as it lies within the equatorial zone. Previous study showed that the prevalence of $25(\mathrm{OH}) \mathrm{D}$ deficiency among Indonesian elderly women in institutionalized care is about $35.1 \%$ [3]. Recent study from Indonesian showed that prevalence of vitamin D deficiency were $23.0 \%$ [4].

Vitamin D has been proven to enhance expression of anti- oxidation-related genes, modulates adaptive immunity, and improves cellular immunity $[5,6]$. The protective effect of vitamin D against COVID-19 is related to suppression of cytokine response and reduced severity/risk for ARDS. The evidence from a meta-analysis that regular oral vitamin D2/D3 intake (in doses up to 2000 $\mathrm{IU} / \mathrm{d}$ without additional bolus), is safe and protective against acute respiratory tract infection, especially in subjects with vitamin $D$ deficiency [7]

There were no proven therapy for COVID-19 yet. Previous studies showed the plausibility of Vitamin D prophylaxis and therapy for COVID-19, particularly in settings where hypovitaminosis $D$ is frequent. The examination of Vitamin $D$ status is not a routine in Indonesian clinical setting. The aim of our study was report case series of Vitamin D status in patients with confirmed COVID-19 and review recent literature on the role of Vitamin D on COVID-19.

\section{Methodology}

Case series from confirmed cases of COVID-19 in Bethesda hospital Yogyakarta, Indonesia. The data of clinical symptoms, clinical signs, and laboratory examination were obtained from electronic medical record. The data were analyzed descriptively. This study obtained EC and permission from Bethesda hospital Yogyakarta, Indonesia.

The vitamin D status was measured by standardized laboratory method. The Vitamin D examination was used VIDAS $250 \mathrm{OH}$ Vitamin D (bioMerleux Marcy l'Etolie France) for Vitamin D2 and DE3 with Enzyme Linked Fluorescence Assay. Measurement of $25(\mathrm{OH})$ vitamin $\mathrm{D}$ serum were done by enzyme immunoassays for the quantitative measurement of total serum $25(\mathrm{OH})$ vitamin $\mathrm{D}$ levels. The levels $<10 \mathrm{ng} / \mathrm{dL}$ is deficiency, $10-29 \mathrm{ng} / \mathrm{dL}$ is in-sufficiency, and $30-100 \mathrm{ng} / \mathrm{dL}$ is sufficiency. 
We searched PubMed and Google Scholar for studies that included terms for Vitamin D and COVID-19. We found no trials of Vitamin D in COVID-19 that have reported results. We did find several studies that are registered, but have not yet reported. None seemed to be masked comparisons to placebo.

\section{Results}

Herein we report that there were 10 participants with COVID-19 consisting of 50\% (5 patients) Male and 50\% (5 patients) Female. All the patients had either positive serological and real time PCT test for COVID-19. The average age of participants was 49.6 years. Symptoms felt by patients vary and some with asymptomatic. For comorbidities that are owned by patients also vary; $40 \%$ have a history of hypertension, $10 \%$ patients with diabetes, $10 \%$ patients with COPD, and $10 \%$ post stroke.

Based on laboratory tests, $90 \%$ (9 patients) had vitamin D deficiency status (vitamin D levels $<20 \mathrm{ng} / \mathrm{mL}$ ) where 3 out of 10 patients had vitamin $<8.1 \mathrm{ng} / \mathrm{mL}$ and $10 \%$ (1 patient) had vitamin D insufficiency status (vitamin D levels $20-29 \mathrm{ng} / \mathrm{mL}$ ) and there were no patients with normal or adequate vitamin $\mathrm{D}$ levels. The results of other blood tests can be seen in Table 1.

Table 1 Demographics, Clinical Characteristics on Admission and Laboratory Results of 10 patients cases with COVID-19 Infection

\begin{tabular}{|c|c|c|c|c|c|c|c|c|c|c|c|}
\hline & Patient 1 & Patient 2 & Patient 3 & Patient 4 & Patient 5 & Patient 6 & Patient 7 & Patient 8 & & \multicolumn{2}{|c|}{ Patient 10} \\
\hline \multicolumn{12}{|l|}{ Demographics } \\
\hline Age (years) & 49 & 51 & 17 & 40 & 65 & 73 & 14 & 54 & 69 & 64 & \\
\hline \multicolumn{12}{|c|}{ Mean of age $=49.6$ years } \\
\hline Gender & Female & Male & Male & Male & Female & Male & Female & Female & Female & Male & \\
\hline \multicolumn{12}{|c|}{ Clinical Findings on Admission } \\
\hline Symptom & $\begin{array}{l}\text { Fatigue(close } \\
\text { contact) }\end{array}$ & $\begin{array}{l}\text { Fever, } \\
\text { diarrhea }\end{array}$ & $\begin{array}{l}\text { No } \\
\text { symptoms } \\
\text { (close } \\
\text { contact) }\end{array}$ & $\begin{array}{l}\text { Fever, } \\
\text { fatigue, } \\
\text { dry cough }\end{array}$ & $\begin{array}{l}\text { Fever, } \\
\text { fatigue, } \\
\text { headache }\end{array}$ & $\begin{array}{l}\text { Fever, } \\
\text { fatigue, dry } \\
\text { cough, }\end{array}$ & $\begin{array}{l}\text { No } \\
\text { symptoms, } \\
\text { (close } \\
\text { contact) }\end{array}$ & $\begin{array}{l}\text { Fatigue, } \\
\text { non } \\
\text { specific } \\
\text { headache }\end{array}$ & \multicolumn{2}{|c|}{ Fatigue, dry } & $\begin{array}{l}\text { Fever, dry } \\
\text { cough }\end{array}$ \\
\hline Comorbidity & - & Diabetes & - & - & Hypertension & $\begin{array}{l}\text { Hypertension, } \\
\text { COPD }\end{array}$ & - & - & \multicolumn{2}{|c|}{ Hypertension } & $\begin{array}{l}\text { Post Stroke, } \\
\text { Hypertension }\end{array}$ \\
\hline SARS-CoV IgG & Positive & Positive & Positive & Positive & Positive & Positive & Positive & Positive & \multicolumn{2}{|l|}{ Positive } & Negative \\
\hline SARS-CoV IgM & Positive & Positive & Positive & Positive & Positive & Positive & Positive & Positive & \multicolumn{2}{|l|}{ Positive } & Positive \\
\hline \multicolumn{12}{|l|}{ Laboratory Results } \\
\hline $\begin{array}{l}\text { Vitamin D Levels } \\
(\mathrm{ng} / \mathrm{mL})\end{array}$ & $<8.1$ & 10.6 & 20.5 & 11.9 & 11.6 & 12.4 & 8.3 & 10.1 & $<8.1$ & & $<8.1$ \\
\hline Vitamin D Status & Deficiency & Deficiency & Insufficiency & Deficiency & Deficiency & Deficiency & Deficiency & Deficiency & \multicolumn{2}{|c|}{ Deficiency } & Deficiency \\
\hline Hemoglobin $(\mathrm{g} / \mathrm{dL})$ & 12.4 & 16 & 17.6 & 14.3 & 12.6 & 13.5 & 14.6 & 12.2 & \multicolumn{2}{|l|}{10.7} & 12.4 \\
\hline $\begin{array}{l}\text { White Blood Cell } \\
\left(10^{3} / \mu \mathrm{l}\right)\end{array}$ & 6.80 & 7.14 & 6.81 & 6.94 & 7.62 & 5.62 & 5.64 & 7.07 & \multicolumn{2}{|l|}{5.97} & 9.84 \\
\hline
\end{tabular}




\begin{tabular}{|l|l|l|l|l|l|l|l|l|l|} 
Red Blood Cell & 3.94 & 5.14 & 6.21 & 5.11 & 4.21 & 4.38 & 5.01 & 4.31 & 3.34 \\
$(\mathbf{1 0} / \mathbf{\mu l})$ & & & & & & & & & \\
\hline Platelets $\left(10^{3} / \mathbf{\mu l}\right)$ & 451 & 174 & 289 & 384 & 542 & 184 & 290 & 190 & 312 \\
\hline Lymphocyte(\%) & 24.0 & 16.8 & 29.7 & 30.1 & 25.9 & 24.2 & 20.7 & 16.5 & 19.9 \\
\hline
\end{tabular}

\section{Discussion}

Here we report our findings in 10 patients with confirmed COVID-19 infection hospitalized patients from Bethesda Hospital, Yogyakarta Indonesia. Patients in this case were conducted from 50\% (5 patients) male and 50\% (5 patients) female with an average age of 49.6 years. The incubation period for COVID 19 in this case is 2-14 days. Our study showed that elderly and female tends to have lower vitamin D status. This is relevant with the facts on vitamin D and COVID-19. Serum 25(OH)D concentrations tend to decrease with age [8]. In COVID-19 case-fatality rates (CFRs) increase with age [9].

We found out that COVID-19 patients in this case had several comorbidities which are chronic diseases such as hypertension, diabetes, COPD, and post stroke. Some studies report that people with chronic disease co-morbidities have lower 25(OH)D than healthy people [10]. Case Fatality Rate (CFR) in China is $6 \%-10 \%$ for those with cardiovascular disease, hypertension, diabetes, and chronic respiratory diseases [9].

In this case series, we evaluated vitamin D status in 10 patients with COVID-19. Examination of vitamin D levels was carried out by blood tests in the laboratory. From 10 patients, we found 90\% (9 patients) with vitamin D deficiency and 10\% (1 patient) with vitamin D insufficiency. Some of the patients have very severe deficiency. Similar to our findings, previous studies reported COVID19 patients among ICU subjects, 11 (84.6\%) had Vitamin D insufficiency vs 4 (57.1\%) of floor subjects. Surprisingly, 100\% of ICU patients who are less than 75 years old have Vitamin D Insufficiency $(n=11)$. Among these, $64.6 \%(n=7)$ had very low $25(\mathrm{OH}) \mathrm{D}$ levels $<20 \mathrm{ng} / \mathrm{mL}$ and three had 25(OH)D levels $<10 \mathrm{ng} / \mathrm{mL}[11]$.

Recent study from Martineau, et al. were performed a meta-analysis from 25 randomized controlled trials (10.933 participants). There was a statistically significant reduction found from vitamin $D$ supplementation in the risk of having acute respiratory infection. In subgroup analysis, they found a protective effect in daily or weekly supplementation but not in bolus doses. There was a strong protective effect in those with $25(\mathrm{OH}) \mathrm{D}$ levels $<10 \mathrm{ng} / \mathrm{mL}$ and there was no significant effect in those with serum $25(\mathrm{OH}) \mathrm{D}>10 \mathrm{ng} / \mathrm{mL}$. There were an inverse relationship between serum vitamin D levels and risk of acute respiratory tract infection [7]. It means, low vitamin D levels may contribute to increased risk of respiratory infection including COVID-19 [12].

Previous report have speculated that people with low serum vitamin D might be at higher risk of infection with COVID-19, or will be worsen when infected [13]. There is an overlap between groups at high risk of Vitamin D deficiency and groups at high risk of severe COVID-19. Examples include people with chronic disease, and elderly. Our studies showed that some of the COVID-19 cases were elderly, and have chronic disease.

The seasonality of many viral infections, one of them is a respiratory viral infection, is associated with a low concentration of 25(OH)D, as result a UVB doses are low because of winters in temperate climates and rainy seasons related in tropical climates [14]. Our study showed that all patients have deficient and insufficient status of vitamin D. The surprising facts in tropical country that very rich with sun.

Vitamin D have possible beneficial effects in the immune system especially in COVID-19 patient. For example, vitamin D will increase the production of various peptides by the innate immune system, which has anti-viral, anti-microbial and anti-fungal activity [15]. Vitamin $D$ has been proven to not only reduce the production of proinflammatory Th1 cytokines but also to increase the expression of anti-inflammatory cytokines by macrophages. This may be worth bearing in mind the proinflammatory cytokine environment observed in patients infected with COVID-19 and how the "cytokine storm" that leads to acute respiratory distress syndrome [16]. 
We found no trials of Vitamin D in COVID-19 that have reported results. We did find several studies that are registered, but have not yet reported. One trial is testing whether a single oral dose of $25,000 \mathrm{IU}(625 \mu \mathrm{g})$ of vitamin D will improve mortality in patients who are infected with SARS-CoV-2 but do not have severe symptoms, compared with usual care [17]. Another RCT will compare single doses of vitamin D3, 50,000 IU to 200,000 IU (1250 Vs $5000 \mu \mathrm{g})$ in people with COVID-19 pneumonia who are over 75 years of age, or over 70 with low oxygen saturations; the primary outcome measure is mortality at 14 days [18].

We found no clinical evidence that vitamin D supplements are beneficial in preventing or treating COVID-19. We would need evidence from well-masked randomized trials to determine if there are effects, before recommending vitamin D3 supplements for treating or preventing COVID-19 infection. The hypothesis that vitamin D supplementation can reduce the risk of influenza and COVID-19 incidence and death should be investigated in trials to determine the appropriate doses, serum 25(OH)D concentrations, and the presence of any safety issues.

People at risk of vitamin D deficiency should in any case take supplements in line with current guidance. In our case series we treat all our patient with $2000 \mathrm{IU}$ oral supplementation. As clinicians, we should continue to treat people with vitamin D deficiency, but not because of any possible association with respiratory infection.

\section{Conclusion}

The prevalence of vitamin D deficiency in this case series in Bethesda Hospital Yogyakarta, Indonesia is $90 \%$ and $10 \%$ vitamin D insufficiency. Hypothetical review showed that Vitamin D supplementation may be benefit for COVID-19. We found no clinical evidence that vitamin D supplements are beneficial in preventing or treating COVID-19.

\section{Abbreviations}

COVID: Corona Virus Disease, SARS: Severe Acute Respiratory Syndrome, MERS: Middle East Respiratory Syndrome, CFR: Case Fatality Rate, RCT: Randomized Controlled Trial.

\section{Declarations}

\section{Acknowledgements}

Not applicable

\section{Authors' contributions}

RTP, A, AWP designed the study. RTP retrieved the data. A, AWP analyzed the data descriptively. RTP, A, AWP wrote the manuscript. All authors approved the final version of the manuscript.

\section{Funding}

There was no funding that supports this paper.

\section{Availability of data and materials}

Study's data can be accessed from RTP after permission and approval from the Bethesda Hospital Yogyakarta Indonesia.

\section{Ethics approval and consent to participate}

We declare that this study was carried out after obtaining an Ethical clearance certificate was obtained from Bethesda Hospital Yogyakarta as an institution that grants research permission. Ethical clearance certificate number $18(\mathrm{EC} / 18 / 2020)$ Bethesda Hospital Yogyakarta, Indonesia. Authorization from Bethesda Hospital was obtained to conduct this study. All patients' privacy and confidentiality were strictly observed throughout the study. We have also give informed consent and obtained the consent of the patients involved in this study. 


\section{Consent for publication}

The manuscript does not contain any identifying individual personal data in any form.

\section{Competing interests}

All authors declare no conflict of interest.

\section{Authors Information}

Rizaldy Taslim Pinzon : Duta Wacana Christian University Medical of School, Bethesda Hospital Yogyakarta, Angela and Andryawan Wahyu Pradana : Duta Wacana Christian University Medical of School.

\section{References}

1. Zhu N, Zhang D, Wang W, Li X, Yang B, Song J, Zhao X, Huang B, Shi W, Lu R, et al. A Novel Coronavirus from Patients with Pneumonia in China, 2019. N. Engl. J. Med. 2020. https://doi:10.1056/NEJMoa2001017.

2. Zhong NS, Zheng BJ, Li YM, Poon LLM, Xie ZH, Chan KH, Li PH, Tan SY, Chang Q, Xie JP, et al. Epidemiology and cause of severe acute respiratory syndrome (SARS) in Guangdong, People's Republic of China, in February, 2003. Lancet. 2003;362:1353-1358. htpps://doi:10.1016/s0140-6736(03)14630-2.

3. Setiati S. Vitamin D status among Indonesian elderly women living in institutionalized care units. Acta Med Indones.2008;40(2):78-83.

4. Raharusun, Prabowo and Priambada, Sadiah and Budiarti, Cahni and Agung, Erdie and Budi, Cipta. Patterns of COVID-19 Mortality and Vitamin D: An Indonesian Study. 2020. Available at SSRN:https://ssrn.com/abstract=3585561

5. Greiller CL, Martineau AR. Modulation of the immune response to respiratory viruses by vitamin D. Nutrients. 2015;7:42404270. http://doi:10.3390/nu7064240.

6. Zdrenghea MT, Makrinioti H, Bagacean C, Bush A, Johnston SL, Stanciu LA. Vitamin D modulation of innate immune responses to respiratory viral infections. Rev Med Virol. 2017;27.https://doi.org/10.1002/rmv.1909.

7. Martineau AR, Jolliffe DA, Hooper RL, et al. Vitamin D supplementation to prevent acute respiratory tract infections: systematic review and meta-analysis of individualparticipant BMJ.2017;356:i6583. https://doi.org/10.1002/rmv.1909.

8. Vasarhelyi, B.; Satori, A.; Olajos, F.; Szabo, A.; Beko, G. Low vitamin D levels among patients at Semmelweis University: Retrospective analysis during a one-year period. Orv. Hetil. 2011;152:1272-1277.

9. Novel, CPERE. The epidemiological characteristics of an outbreak of 2019 novel coronavirus diseases (COVID-19) in China. Zhonghua Liu Xing Bing Xue Za Zhi. 2020;41:145-151.https://doi:10.3760/cma.j.issn.0254-6450.2020.02.003.

10. Grant WB, Lahore H, McDonnell SL, Baggerly CA, French CB, Aliano JL, Bhattoa HP. Evidence that Vitamin D Supplementation Could Reduce Risk of Influenza and COVID-19 Infections and Deaths. Nutrients. 2020:12;https://doi:10.3390/nu12040988.

11. Lau FH, et al. Vitamin D Insufficiency is Prevalent in Severe COVID-19. medRxiv. 2020 https://doi.org/10.1101/2020.04.24.20075838

12. McCartney DM, Byrne DG. Optimisation of Vitamin D status for enhanced immune-protection against COVID-19. Ir Med J. 2020;113(4):58.

13. ICNARC report on COVID-19 in critical care. 2020; 1-9.www.icnarc.org

14. Nam HH, Ison MG. Respiratory syncytial virus infection in adults. BMJ. 2019;366: I5021. https://doi:10.1136/bmj.I5021.

15. Herr C, Shaykhiev R, Bals R. The role of cathelicidin and defensins in pulmonary inflammatory diseases. Expert Opin. Biol. Ther. 2007;7:1449-1461.

16. Sharifi A, Vahedi H, Nedjat S, Rafiei H, Hosseinzadeh-Attar MJ. Efect of single-dose injection of vitamin D on immune cytokines in ulcerative colitis patients: A randomized placebo-controlled trial. 2019;127,:681-687.

https://doi:10.1111/apm.12982. 
17. Castillo MJ. Vitamin D on Prevention and Treatment of COVID-19 (COVITD-19) [Internet].NCT04334005 2020.Available from: https://clinicaltrials.gov/ct2/show/NCT04334005.

18. Annweiler C. COVID-19 and Vitamin D Supplementation: a Multicenter Randomized Controlled Trial of High Dose Versus Standard Dose Vitamin D3 in High-risk COVID-19 Patients (CoVitTrial). 2020.

https://clinicaltrials.gov/ct2/show/record/NCT04344041. 